\title{
Bahasa sebagai Produk Hukum: Kasus Tindak Pidana Pengadilan Negeri Kota Palopo Sebuah Kajian Stuktrur Skematika Genre
}

\author{
Besse Herdiana, Musfirah \\ Universitas Cokroaminoto Palopo \\ besse@uncp.ac.id
}

\begin{abstract}
Abstrak
Penelitian ini merupakan penelitian kualitatif deskriptif yang bertujuan untuk mendapatkan gambaran mengenai struktur sekematika wacana pada dokumen hasil siding pengadilan negeri palopo. Sumber data dalam penelitian ini adalah teks dokumen hasil sidang Pengadilan Negeri Kota Palopo. Pengumpulan data dilakukan dengan cara observasi dan pengambilan data/dokumen hasil siding yang telah diarsipkan oleh kantor Pengadilan Negeri Kota Palopo. Data/ dokumen hasil siding dianalisis dengan menggunakan teori sistemik fungsional. Data yang telah dianalisis kemudian disajikan hasilnya dalam bentuk laporan berupa penjelasan lengkap secara deskriptif terkait objek yang diteliti dalam hal ini struktur skematika genre teks dokumen hasil sidang tindak pidana kantor Pengadilan Negeri Kota Palopo. Hasil penelitian menunjukkan bahwa dokumen hasil sidang pada dasarnya memiliki struktur yang bertujuan untuk mengetahui, menjelaskan, memaparkan, serta membuktikan tindak pidana yang dilakukan oleh terdakwa. Struktur skematika/genre yang membangun teks wacana hasil sidang dibagi ke dalam beberapa struktur umum yaitu; identifikasi, pemaparan/penjelasan, pengajuan saksi-saksi, putusan/mengadili.
\end{abstract}

Kata kunci: Skematika genre, Tindak Pidana

\section{Pendahuluan}

Bahasa dalam konteks universal adalah bahasa yang merujuk pada fungsinya sebagai komunikasi atau penghubung. Di dalam konteks-konteks tertentu, selain memenuhi fungsinya sebagai alat komunikasi, misalnya di bagian forensic bahasa semacam salah satu alat untuk 'membaca' masalah hukum. Membaca dalam artian bahasa digunakan untuk interpretasi produk hukum, barang bukyi dan hal lainnya. Fenomena kebahasaan dalam perkembangannya kemudian tidak hanya berbicara pada konsep penutur dan lawan tutur, makna tuturan, struktur bahasa atau dikenal dengan kajiankajian linguistic yang bersifat murni seperti fonolohi, morfologi, semantic, sintaksis serta analisis wacana untuk tingkatan penggunaan bahasa dan konteksnya. Untuk cakupan yang lebih luas bahasa dijadikan sebagai alat untuk menelaah dokumen-dokumen hukum.

Bahasa sebagai produk hukum baik tulisan maupun lisan secara fungsional memiliki struktur skematika atau yang dikenal dengan istilah 'genre'. Dalam pandangan linguistic sistemik fungsional 'genre' atau struktur skematika berfokus pada struktur yang membangun sebuah teks/wacana sebagai bentuk hubungan antara satu wacana dengan wacana lainnya sehingga menjadi suatu wacana yang memiliki susunan tata bahasa.

Dokumen hasil sidang dalam sebuah proses pengadilan adalah sebuah teks, sebuah wacana yang berisi laporan kejadian perkara atau kasus yang bersifat factual. Informasi ini akan menjadi tertata dengan baik jika disampaikan secara runut dan jelas. Sebuah teks wacana akan menjadi tertata rapi jika memiliki kesatuan struktur 
pembangun dalam hal ini skematika teks yang tercakup dalam bagian linguistic sistemik fungsional.

Secara garis besar Sinar membuat tiga kategorisasi untuk istilah TLSF. Istilah yang pertama adalah TL, dalam penjabarannya TL ini memiliki dua implikasi. Pertama, bahwa analisis wacana mengadopsi sebuah teori bahasa yang merepresentasikan suatu teori khusus dan juga memasukkan kerangka analisis wacana ke dalam disiplin ilmu linguistic dengan merujuk pada teori linguistic sistemik fungsinonal. Kedua, dalam menganalasisi fenomena analisis wacana mengaplikasikan landasan bahasa secara interpretatif yang bersifat semiotic, tematis dan antardisiplin (2009: 14) . istilah yang kedua adala F (fungsional). Asumsi dari Sinar mengindikasikan bahwa analisis wacana memberikan perhatian kepada (1) realisasi fungsional, (2) fungsi-fungsi atau makna-makna yang ada dalam bahasa. (3) fungsi-fungsi yang terjalin dalam berbagai variasi bahasa yang dikaji. Istilah yang ketiga adalah $\mathrm{S}$ (sistemik). $\mathrm{S}$ ini merujuk pada tiga hal, yang pertama adalah hubungan sistemik, yang kedua adalah system-sistem makna yang terlibat sesuai dengan objek kajian dan yang ketiga adalah system makna yang menjadi dasar fenomena yang sedang dikaji (Sinar, 2009: 15)

Oleh pakar linguistik sistemik fungsional posisi 'genre' setara dengan konteks situasi pada taraf semiotik konotatif. Apa yang dimaksud dengan semiotik konotatif? Dalam pandangan Sinar bahasa adalah satu sistem semiotik sosial dan hidup dalam konteks. Sebagai system semiotic, bahasa bersosialisasi dengan system-sistem semiotik lain serta meminjam sistem-sistem semiotic, misalnya system semiotic konteks. Hubungan bahasa dengan konteks adalah realisasi bahasa sebagai sebuah system semiotic sosial. Dengan kata lain, bahasa wujud dalam konteks dan tiada bahasa tanpa konteks sosial.

Malonowski seperti yang dikutip oleh Sinar (2008: 67) menegaskan bagaimana relasi sosial yang terjadi, yang dilatarbelakangi oleh konteks budaya dan konteks sistuasi. Menurutnya, interaksi kontak sosial terjadi dalam sua strata yaitu konteks situasi dan konteks budaya dengan landasan bahwa teks hanya bis ajika berkaitan dengan dua strata ini. Dalam teori yang lain, seperti yang dikemukakan oleh Bernstein orientasi coding seseorang menjadi lebih terorganisisr dengan baik, sebagaimana mereka belajar untuk mengenali dan menerapkan susuna ragam konteks yang lebih banyak. Perbedaanperbedaan pengalaman dalam sosial budaya akan menciptakan akses yang berbeda pada system genre yang telah berkembang dalam suatu budaya.

Para pakar yang terlibat dalam linguistic sistemik fungsional khususnya topik yang berhubungan dengan konteks budaya genre, melihat teks sebagai suatu pola. Struktur. Pola inilah yang kemudian membentuk makna interpersonal dan fungsi sosial teks. Hasan dan Martin (Sinar, 2009: 68) pernah menganalisis setruktur cerita dengan menggunakan teori yang diperkenalkan oleh Halliday 'variabel register' dari hasil analisis tersebut menghasilkan gagasan bahwa bahasa sebagai teks bisa dijelaskan dan dipahami secara sistematis melalui konteks situasi. Sementara Martin mengambil teori fungsional dari Gregory.

Hasil dari pandangan Hasan dan Martin kemudian disimpulkan oleh Sinar bahwa persamaan kedua teori, anatar Hasan dan Martin terletak pada mereka yang menganggap bahasa dan teks memiliki pola bentuk 'overall' yaitu struktur awal, tengah dan akhir. Lebih lanjut, Sinar memaparkan bahwa konsep genre sebagai usaha melingkupi unsur fungsional, aspek atau dimensi yang secara umum dikenal dengan istilah, maksud, matlamak, objektif, sasaran atau tujuan. Di dalam sebuah interaksi sosial sebagai bentuk kegiatan manusia atau masyarakat dalam budaya tertentu, atau di dalam wacana 
manusia di dalam teks, penutur suatu budaya seharusnya memiliki tujuan atau maksud yang khas bagi budaya tersebut. Tujuan ini kemudian menjadi suatu factor-faktor yang memotivasi dan menentukan di dalam perkembangan interaksi sosial atau pencipta teks $(2009 ; 68)$.

\section{Metode Penelitian}

Pengumpulan data

Pengumpulan data dilakukan dengan cara:

a. Observasi awal, dilakukan dengan cara bertemu dengan pimpinan kantor Pengadilan Negeri Kota Palopo untuk meminta izin mengambil data sekaligus wawancara singkat tentang proses persidangan

b. Pengambilan data/dokumen hasil siding yang telah diarsipkan oleh kantor Pengadilan Negeri Kota Palopo

Analisis Data

Data/ dokumen hasil siding dianalisis dengan menggunakan teori sistemik fungsional

Penyajian Data

Data yang telah dianalisis kemudian disajikan hasilnya dalam bentuk laporan berupa penjelasan lengkap secara deskriptif terkait objek yang diteliti dalam hal ini struktur skematika genre teks dokumen hasil siding tindak pidanan kantor Pengadilan Negeri Kota Palopo.

\section{Hasil Dan Pembahasan}

Pada bagian ini diuraikan hasil penelitian terhadap analisis pada data yang telah diambil dari lapangan. Uraian hasil penelitian terdiri atas dua bagian. Bagian pertama merupakan bukti yang diperoleh dari hasil analisis data yang dilengkapi dengan kutipan teks. Bagian kedua merupakan pembahasan terhadap hasil penelitian.

\section{Penyajian Data}

\section{Struktur Skematika Wacana}

Skematika atau struktur generik teks adalah pola umum yang mengorganisir sebuah teks. Berikut analisis struktur yang membangun pada teks hasil putusan sidang Pengadilan Negeri Palopo :

\section{Bagian 1}

Demi Keadilan Berdasarkan Ketuhanan Yang Maha Esa Pengadilan Negeri Palopo yang mengadili perkara pidana dengan acara pemeriksaan biasa dalam tingkat pertama menjatuhkan putusan berikut dalam perkara terdakwa :

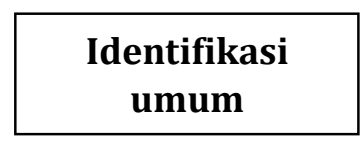
1. Nama Lengkap
2. Tempat Lahir
3. Umur/tanggal lahir
4. Jenis Kelamin
5. Kebangsaan
6. Tempat Tinggal
7. Agama
8. Pekerjaan

Terdakwa Nandi Hermawan Ramlan Alias Nandito Bin

Ramlan Paressa ditahan dalam tahanan rutan oleh : 
1. Penyidik sejak tanggal 26 Februari 2019 sampai dengan Tanggal 17 Maret 2019

2. Penyidik perpanjangan oleh penuntut umum sejak tanggal 18 Maret 2019 sampai dengan tanggal 27 April 2019

3. Penuntut umum sejak tanggal 10 April 2019 sampai dengan Tanggal 29 April 2109

4. Hakim Pengadilan Negeri sejak tanggal 22 April 2019 sampai Tanggal $21 \mathrm{Mei}$ 2019

5. Perpanjangan Ketua Pengadilan Negeri sejak tanggal 22 Mei 2019 sampai dengan tanggal 20 Juli 2019

Terdakwa menghadap sendiri dipersidangan, meskipun hak untuk didampingi

oleh penasihat hukum telah ditawarkan sebagaimana oleh Majelis Hakim;

Identifikasi umum menyajikan informasi berisi tentang identitas terdakwa berupa nama, tempat lahir, umur, jenis kelamin, kebangsaan, alamat/tempat tinggal, agama dan pekerjaan. Pada data yang menjadi terdakwa adalah Nandi Hermawan dengan tuntutan kekerasan dalam rumah tangga.

\section{Bagian 2}

Struktur yang kedua adalah pembacaan tuntutan, informasi yang disampaikan pada pembacaan tuntutan adalah informasi yang terkait dengan jenis tuntutan, waktu dan tempat terjadinya perkara, cara atau mekanisme tindak pidana, dasar penjatuhan tuntutan.

Setelah mendengar pembacaan tuntutan pidana yang diajukan oleh penuntut umum yang pada pokoknya sebagai berikut

1. Menyatakan terdakwa Nandi Hermawan Ramlan alias Nandito Bin Ramlan Paressa telah terbukti secara sah dan meyakinkan melakukan tindak pidana "Kekerasan Fisik dalam Rumah tangga" yang diatur dan diancam pidana dalam pasal 44 ayat (1) UU No.23 Tahun 2004 tentang penghapusan kekerasan dalam rumah tangga sebagaimana dalam surat dakwaan kami.

2. Menjatuhkan pidana terhadap terdakwa Nandi Hermawan Ramlan alias Nandito Bin Ramlan Paressa dengan pidana penjara selama 1 (satu) tahun dikurangi selama terdakwa menjalani tahanan dengan perintah terdakwa untuk tetap ditahan;

3. Menetapkan barang bukti berupa: satu buah kutipan akta nikah (buku nikah) Kantor Urusan Agama Kec. Telluwanua Kota Palopo, nomor: 57/7V/2015, atas nama Le. Nandi Hermawan Ramlan alias Nandito Bin Ramlan Paressa dan perempuan a.n Windi Andriani Pongsibanne alias Windi Binti Andri Pongsibanne, dikembalikan kepada pemiliknya a.n Windi Andriani Pongsibanne

4. Menetapkan agar terdakwa dibebani biaya perkara sebesar Rp,2.000 


\section{Bagian 3}

Menimbang, bahwa untuk membuktikan dakwannya penuntut umum telah mengajukan saksi-saksi sebagai berikut:

1. Saksi Windi Andriani pongsibanne Alias Windi Binti Andri pongsibanne dibawah sumpah menerangkan sebagai sebagai berkit:

a) Bahwa sakasi dalam keaadaan sehat jasmani dan rohani dan mengerti memberikan keterangan persidangan ini berkaitan dengan masalah penganiayaan terhadap diri saksi yang dilakukan oleh terdakwa

b) Membawa saksi adalah istri dari terdakwa

c) Bahwa keterangan yang diberikan saksi pada waktu penyidikan di kepolisian adalah benar semua dan diberikan secara jujur tanpa adanya tekanan dari pihak mana pun

d) Bahwa saksi korban menikah dengan dakwa pada tanggal 10 september 2014 dan telah dikarunia 2 orang anak dan saksi menikah dengan dakwa secara sah menurut hukum yang berlaku karena saksi memiliki buku akta nika nomor 47/7/v/2015 yang dikeluarkan oleh KUA kec.Talluwanua,kota palopo

e) Bahwa kejadian penganiayaan pada hari senin,tanggal 25 februari 2019, sekitar pukul 16.30 wita, bertempat di lingkunagan, lelong, kelurahan jaya, kecematan Talluwanua kota palopo:

f) Bahwa berawal ketika saksi korban sedang berada dalam kios miliknya, kemudian datang Lel.Alif yang berupakan teman terdakwa ingin membeli es batu namun pada saat itu saksi korban mengatakan bahwa es batu habis ,tidak lama kemudian terdakwa masuk kedalam kios dan mengambil es batu didalam kulkas lalu saksi menegur terdakawa

g) Bahwah akibat penganiayaan tersebut saksi kornan mengalami luka lecet berdarah bagian lulut seblah kiri

h) Bahwa sekarang saksi korban sudah beraktifitas kembali

i) Bahwa saksi korban sudah memanfaatkan perbuatan terdakwa

j) Bahwa saksi korban dan terdakwa berdamai di persidangan

2. Saksi Julia Alias mama Candra Binti Gambu bibawah sumpah menerangkan sebagai berikut:

a. Bahwa saksi dalam keadaan sehat jasmani dan rohani dan mengerti memberikan keterangan di persidangan ini berkaitan dengan masalah penganiayaan terhadap diri saksi Windi yang dilakukan terdakwa 
b. Bahwa saksi kenal dengan terdakwa dan tidak ada hubungan keluarga karena darah maupun karena perwakilan ;

c. Bahwa keterangan yang berikan saksi pada waktu menyidikan di kepolisian adalah benar semua dan diberikan secara jujur tandapa adanya tekanan dari pihak maunapun;

d. Bahwa saksi adalah tetangga dari berdakwa, dan setahu saksi hubungan bedakwa dengan saksi korban adalah suami istri ;

e. Bahwa kejadian penganiayaan pada hari senin,tanggal 25 februari 2019,sekitar pukul 16.30 wita, bertempat di lingkungan lelong kelurahan jaya, kecamatan Talluwanua, kota palopo

f. Bahwa pada saat kejadian saksi sedang berada diluar rumah kemudian melihat terdakwa dan saksi korban Windi bertengkar mulut setelah itu saksi melihat terdakwa menganiaya saksi korban Windi dengan cara terdakwa memukul wajah dan kepala bagian belakang saksi korban Windi berkali kali dengan menggunakan tangan/tinju dan saat itu saksi melihat saksi korban Windi jatuh ketanah singga saksi datang untuk menolong dan membawah kedalam rumah saksi selanjutnya saksi mengobati luka dan lutut,wajah dan kepala saksi korban Windi;

g. Bahwa akibat kejadian penganiyaan tersebut saksi melihat saksi korban luka memar dan benjol dibagian dahi kanan dan kepala bagian belakang dan luka lecet berdarah pada bagian lutut sebelah kiri;

h. Bahwa antara saksi korban dengan terdakwa saling memaafkan dan berdamai

\section{Bagian 4}

Mengadili ;

1. Mengatakan terdakwa Nandi Hermawan Ramlan Alias Nandito Binti Ramlan Peressa telah terbukti secarah sah dan menyakinkan bersaah melalukan tidak pidana "melakukan kekerasan dalam lingkungan kelurga" sebagian dakwaan alternative ke satu penuntut umum;

2. Menjatuhkan pidana terhadap terdakwa oleh karena itu dengan pidana penjara seama 8 bulan

3. Menetapkan pidana yang dijatuhkan dikurangkan sepenuhnya dari masa penangkapan dan penahanan yang telah dijalani oleh terdakwa

4. Menetapkan terdakwa tetap dalam tahanan

5. Menyatakan bukti serat berupa

6. Membebankan kepada terdakwa membayar biaya perkara sebesar Rp. 2.000 
Pada bagian putusan, struktur ini berisi tentang pemberian keputusan hakim kepada terdakwa atas kasus berdasarkan bukti dan pengajuan saksi sekaligus merupakan bagian penutup atau bagian akhir dari struktur wacana. Putusan dibacakan oelh hakim sebagai pelibat wacana berdasarkan bukti-bukti yang ada serta pasal yang mengatur tentang kasus tindak pidana kekerasan dalam rumah tangga.

\section{Pembahasan}

Teks wacana hasil sidang adalah salah satu genre dalam bentuk laporan yang fungsinya untuk mendokumentasikan hasil siding dalam setiap perkara. Teks wacana hasil siding menyajikan informasi yang terkait dengan pelibat, saran dan konteks situasi seperti halnya dengan teks wacana yang lain. Informasi yang disajikan informasi faktual dengan hasil persidangan. Sumber informasi faktual berasal dari hasil persidangan yang terjadi dalam bentuk interaksi lisan yang melibatkan para pelibat wacana, terdakwa, hakim, sakisi-saksi, jaksa penuntut, dan korban.

Pada bagian penyajian data disajikan dua teks wacana tindak pidana, data diatas menunjukkan bahwa struktuk skematika pada teks hasil putusan sidang dengan kasus "Tindak Pidana Kekerasan dalam Rumah Tangga" secara umum terbagi atas 4 truktur yang diawali dengan"Identifikasi umum', 'pembacaan tuntutan', 'pengajuan saksi', 'putusan/mengadili'.

Dokumen teks hasil sidang pada dasarnya memiliki kemiripan dan genre laporan yang mengandung informasi objektif tentang hal-hal yang bersifat faktual. Fungsi genre ini adalah mendokumentasikan hasil persidangan.

a. Identifikasi, merujuk pada identitas umum orang-orang yang terlibat dalam permasalahan atau yang dikenai perkara. Pada bagian ini juga dijelaskan kronologi kejadian kasus dalam istilah genre dikenal dengan istilah 'deskripsi'. Deskripsi yang dimaksud adalah bagian sesuatu bisa terjadi yakni kronologi dari kasus atau peristiwa. Identitas umum yang dimaksud adalah hakim sebagai ketua pelaksana persidangan mengajukan beberapa pertanyaan yang terkait dengan identitas terdakwa, misalnya nama lengkap, tempat lahir, umu/tanggal lahir, jelas kelamin, kebangsaan, tempat tinggal, agama dan pekerjaan.

b. Pemaparan/penjelasan, berisi tentang pembacaan tuntutan dan terdakwa bagi pihak-pihak yang terlibat dengan tindak pidana informasi yang disampaikan pada pembacaan tuntutan adalah informasi yang terkait dengan
a. Jenis tuntutan
b. Waktu, tempat dan suasan
c. Cara (mekanisme tindak pidana)
d. Dasar penjatuhan tuntutan (pasal-pasal)

c. Pengajuan saksi-saksi, berisi tentang orang-orang yang terlibat yang memberikan kesaksian dalam perkara

d. Putusan/mengadili, pada bagian ini berisi tentang kesimpulan akhir hasil dari perkara yakni hakim memberikan informasi berupa putusan yang ditetapkan kepada terdakwa. Bagian putusan atau mengadili menjadi, struktur penutup dari teks wacana hasil sidang. 


\section{Simpulan}

Dokumen hasil sidang pada dasarnya memiliki struktur yang bertujuan untuk mengetahui, menjelaskan, memaparkan, serta membuktikan tindak pidana yang dilakukan oleh terdakwa. Struktur skematika/genre yang membangun teks wacana hasil sidang dibagi ke dalam beberapa struktur umum yaitu; identifikasi, pemaparan/penjelasan, pengajuan saksi-saksi, putusan/mengadili.

\section{Daftar Pustaka}

Budiawan, R.Y. S., Mualafina, R.F., \& Gotik, Z. (2009). Kontropersi Tuturan Artis Zaskia Gotik Dalam.

Piliang, Y. A. (n.d). Forensik Dalam Persfektif Budaya: 367-376.

Subyantoro. (2009). Linguistik Forensik : Sumbangsih Kajian Bahasa dalam Penegakan Hukum. Adil Indonesia Jurnal, 1(3). 61-70.

Gibbons, J. (2007). Forensic Linguistic: an introduction to language in the Justice System. Blackwell.

Coulthard, M. dan Alison Johnson (eds.). (2010). An Introductionto Forensic Linguistics: Language in Evidence. New York: Rouledge. 